\title{
Effect of Graphic Organizer and Instructional Scaffolding on Argumentative Essay Writing Performance: A Critical Analysis
}

\author{
Jayasri Lingaiah*, Saroja Dhanapal** \\ * Faculty of Social Sciences \& Liberal Arts, UCSI University, Kuala Lumpur, Malaysia \\ **Faculty of Law, University of Malaya, Kuala Lumpur, Malaysia \\ DOI: 10.29322/IJSRP.10.10.2020.p10602 \\ http://dx.doi.org/10.29322/IJSRP.10.10.2020.p10602
}

\begin{abstract}
This study investigated the effect of graphic organizer and instructional scaffolding on argumentative essay writing performance among TESL undergraduates. The study employed an experimental research using the pre-test and post-test design involving 60 TESL undergraduates who underwent lessons on argumentative essay writing using two different delivery modes, namely 'Graphic Organizer with Instructional Scaffolding' (GOIS) which is the experimental group and 'No Graphic Organizer No Instructional Scaffolding' (NGNI) which is the control group. The TESL undergraduates of the experimental group went through the GOIS delivery mode comprising four stages of learning; Stage 1: The Introduction; Stage 2: Assisted Group Discussion; Stage 3: Writing an Individual Essay and Stage 4: Peer Review for a duration of four weeks. The control group (NGNI) went through normal delivery mode comprising four stages of learning without the use graphic organiser or instructional scaffolding; Stage 1: The Introduction, Stage 2: Peer Learning, Stage 3: Individual Essay Writing and Stage 4: The Review. A one-way ANCOVA was used to analyse the overall argumentative essay writing performance of the students. Results showed that the group which underwent the GOIS delivery mode performed significantly better in the overall argumentative essay writing performance $(\mathrm{p}<.05)$ compared to the control group which went through the NGNI delivery mode. The research confirmed that the GOIS delivery mode is effective in enhancing argumentative writing performance among TESL undergraduates. In line with this, the research ends with a recommendation for educators to adopt the GOIS delivery mode in the future to ensure that undergraduate students' argumentative writing skills are enhanced.
\end{abstract}

Index Terms- Graphic Organizer, Instructional Scaffolding, Argumentative Essay Writing, Sociocultural Theory, TESL Undergraduates

\section{INTRODUCTION}

Mastering the writing skill is the most challenging and difficult task compared to other language skills (Tayib, 2015). Writing and mastering the argumentative essay, although found to be challenging, is a key skill for writing success (Thompson, 2017) and acknowledged as significant for "general life purposes" (Dastjerdi \& Samian, 2011, p.68). Likewise, presenting arguments in written form is vital as it plays an important role in the social, academic and professional success (NCES, 2012 as cited in Wilson, 2014). The ability to write a quality argumentative essay was noticed to promote the cognitive ability of students to think critically, solve problems, generate and justify solutions, formulate ideas and make decisions (Cho \& Jonassen, 2002). Thus, being able to write a good argument is believed to help students to develop their critical thinking and research skills as well as to develop and logically defend a position (Thompson, 2017).

The essay writing assignments (such as the argumentative writing) is central to most English as a Second Language (ESL) courses in tertiary education in Malaysia (De Rycker \& Ponnudurai, 2011) and is also regarded as an essential form of written discourse specifically in Malaysian University English Test (MUET). The writing component in MUET has been identified as an essential component for undergraduates and contributes as the second-highest weighting $30 \%$ of the overall test (Kanestion et al., 2016). In the component, students are expected to write an argumentative essay. Thus, it becomes imperative to provide sufficient mastery of the argumentative skills among students as MUET is a requirement for entry into graduate programmes.

However, argumentative writing is not an easy communicative task because it requires complex cognitive and linguistic skills (Nippold \& Ward-Lonergan, 2010) and appropriate use of conjunctions as it connects paragraphs, sentences and clauses (Uzun, 2017). The argument is the essence of critical thinking that entails making a case to sustain a claim, identifying supporting evidence from various sources that connect the claim reasonably, using warrants that support the connections between the claim and the supporting evidence as well as backing the warrants with support (Hillocks, 2011). Thus, undergraduates are urged to master all the above-mentioned skills not only in TESL but also in all other courses to create reliable and persuasively written arguments based on acceptable logical support (Botley \& Hakim, 2014). In essence, the ability to write an argumentative essay at

This publication is licensed under Creative Commons Attribution CC BY. 
the tertiary level does not only assist undergraduates to become critical thinkers but also reflective thinkers (Ponnudurai, 2011) who can convey personal opinions effectively (Ka-kan-Dee \& Kaur, 2015).

Today, many young adults enter tertiary education without the skills needed to think critically and to construct cogent arguments (Kellogg \& Whiteford, 2009). Previous studies have also discovered that ESL students at the tertiary level lack proficiency in writing argumentative essays (Spawa \& Hassan, 2013). Based on a study conducted by Saadiah Darus (2009 as cited in Mohamed, 2016), Malaysian ESL students are weak in their writing proficiency and encounter many challenges using appropriate words and phrases to convey ideas even though they have been learning the English language for several years. Additionally, Bipinchandra et al. (2014) also discovered that students are not able to relate their ideas in writing as it focuses more on the product than the process of writing and they are not able to grasp the skills needed due to lack of time, especially during groupbased activities. On the other hand, Intaraprawat (2002 as cited in Saito, 2010) asserted that students' inability to compose effective argumentative essays may lie in the difficulties to take a position on controversial issues, provide reasons or supporting evidence to convince or accept their position.

According to Ponnudurai (2011), students at the tertiary level were found to be fluent in their spoken language but unfortunately, they were not able to make discernment, arguments, support or even make reflections in their argumentative writing due to insufficient content. Further, they were also found to have difficulties in using appropriate vocabulary in their writing. Along with this, students were also found to encounter problems using complex syntactic patterns, choosing suitable elements of arguments in composing argumentative essays or arguing and proposing a convincing thesis statement in their argumentative writing (Ka-kan-Dee \& Kaur, 2015). Scholars had also noticed that students lack implicit knowledge about the argumentative conventional pattern, providing clear supporting evidence and refutation (Udomyamokkul, 2004 as cited in Saito, 2010) and have limitations in the use of conjunctions (Mohamed, 2016; Uzun, 2017; Muftah, 2014). As a result, argumentative writing appears as the most challenging type of writing (Ponnudurai, 2011).

One of the reasons for the challenges faced in the argumentative essay writing is the inappropriate teaching methods (Tayib, 2015) and the current instructions used by trainee teachers in argumentative writing which were found to be rather instructorcentred and exam-oriented (Bipinchandra et al., 2014). The lecture method which is employed during instruction in higher institutions has failed to provide appropriate support and scaffolding for the students to write (Hussin, 2008). The lecture method, according to Hussin (2008) requires not only good linguistic competence among educators but also advanced critical thinking skills such as presenting logical and convincing arguments, generating and justifying ideas and evaluating facts to form judgments. Thus, although the lecture method has been conceived as a valuable teaching approach for pedagogical reasons, it is acknowledged that there is a need for the particular method to be improved by incorporating more dialogic and interactive teaching and learning approaches (French \& Kennedy, 2016). According to Zakrajsek (2018), the lecture method can impact negatively on students' learning as it is always linked to lecturer's ineffectiveness of delivering the lesson such as monotone deliveries, boring slide presentation and distributing notes that contain old information.

Further, Mann (2009) also claimed that the lecture method does not offer much room for interaction or active learning environment for students. Mann's findings were further collaborated by Kelly (2017) who affirmed that most college courses are lecture-based for it is and still known as the dominant time-tested instructional method. The lecture method is straightforward and the instructors are the sole source of information with complete control over the lesson. However, according to Kelly (2017), although the lecture method can be very engaging as many educational institutions offer faculty recorded lectures for students, yet, students may also find lectures boring as they are not able to ask questions, challenge each other's thinking, there is no grouping for differentiation and there is no opportunity for instructors to check for students' understanding. Briefly, the lecture method is dull and dreary, as evidenced by Berk's (2009, p.3) research that indicated "about 50\% of college students are unmotivated, disinterested and disengaged from classroom instruction".

Additionally, the way students experience learning (Abdul-Hafid Kamil, 2011; Lap \& Truc, 2014), teachers' practice on teaching and delivering their writing instructions as well as failure to employ effective feedback mechanisms were found to be among the reasons that contribute to writing difficulties among students (Sahin, Bullock \& Stables, 2002). Budimlic (2012) asserts that most instructors give feedback as a one-way practice to assess students' achievement, but the type of feedback in the form of dialogic interaction between student-teacher and student-student at the end of a lesson can be valuable for both parties in helping them to improve and refine their learning and teaching process. According to Vacca, Vacca and Mraz (2011), active engagement in social interaction among students enables them to shoulder their responsibility towards learning. However, Mercer (2008) and Harvey (2011) suggested for the use of exploratory talk among students through adult guidance helps students attain higher-order thinking, improve reasoning skills and become more sophisticated users of the language. But, Zulkurnain and Kaur (2014) pointed out that educators fail to create interactive learning experiences to improve the knowledge of undergraduates in English language (such as the argumentative writing) and this has resulted in poor language proficiency among those groups (Malaysia Today, 2005).

Moreover, various impressions of learning among students have been linked to educators' qualities such as teaching experiences, the field of expertise, the amount of knowledge, competencies, training and professional development (Kepol, 2017). According

This publication is licensed under Creative Commons Attribution CC BY. 
to Chong and Teng (2018, p.103), besides all these qualities “... a good lecturer should always be prepared to listen to students to diagnose their learning progression." But, Goh (2008) discovered that educators did not possess the necessary qualities and there is a lack of pedagogical knowledge. They were found to have problems in directing and supporting their students in comprehending concepts and assisting them to correlate their prior knowledge to new thoughts. Therefore, the problem "had manifested itself in the absence of expertise in the subject matter, unimaginative teaching, inability to relate concept to real situation and the lack of useful and timely feedback" (Goh, 2008, p.66). Additionally, Tucker and Strorage (2005) also pointed out that the educators' teaching quality not only has an effect on how much students learn but also has an effect on students' achievement.

Due to the writing proficiency and pedagogical limitations found in the teaching of writing among TESL undergraduates, there is a need to look for an alternative instructional method that can provide a more conducive and supportive learning environment where the teacher acts as a facilitator and can help their students to achieve their goals (Jumaat \& Tasir, 2014). Additionally, students must have the opportunity to ask questions and provide feedback as well as get support from their peers and educators in learning new tasks. In order to achieve these, students must have interest in the learning material, educator and teaching methods as they are equally important factors for students' achievement and understanding in the subject area (Chukwuagu, 2016). Hawkins (2011) claimed that instructional scaffolding using graphic organizers is the key method that develops students' learning by offering a supportive environment and at the same time cultivate student independence.

Sharrock (2008) pointed out the importance of graphic organizer as an important scaffolding tool that aid students in visualizing connection to their prior knowledge and newly learned knowledge as well as guiding the stages of the writing process. According to Sharrock (2008), the graphic organizer "...depicts the relationships between facts, terms, and or ideas within a learning task" (p.3). Kohler (2009) asserts that the "graphic organizers can be constructed for exploring cause and effect, main idea and details, sequences, decision making, making predictions, and almost any other type of thinking and learning" (p.1). In line with these scholars, Dexter and Hughes (2011) claimed that the graphic organizers are able to improve factual recall of information and students' higher-order thinking skills. They contended that students who were offered the use of completed graphic organizers to write their essays have significantly more relational knowledge statements within their writing compared to those without the use of graphic organizers. Therefore, studies done using the graphic organizers were evident to be significant for students to learn within and beyond classrooms and aid students in their higher-order thinking skills and learning (Sharrock, 2008; Kohler, 2009; Bishop et al., 2015; Miller, 2011).

A wide range of studies has looked into the impact of instructional scaffolding using various strategies on students' writing. Among those studies were teacher prompting techniques in writing performance (Allenger, 2015); strategies-based instruction on learners' writing quality (Rahimi \& Noroozisiam, 2013). Other related studies include direct instruction and strategy modelling on students' writing development (López, Torrance, Rijlaarsdam \& Fidalgo, 2017), scaffolding based instruction in writing performance (Obeiah \& Bataineh, 2015), scaffolded instruction to optimize learning (Larkin, 2002) and Toulmin Model of Argument on the problem-solving strategies (Wilson, 2014). Additionally, other scholars have also looked into the efficacy of graphic organizers and instructional scaffolding in writing in various contexts to promote integration of arguments and counterargument (Nussbaum \& Schraw, 2007), summary writing (Fergus, 2009), genre-specific writing tasks (Hawkins, 2011), students' revision in the pre-writing stages (Lee, 2007) and teaching writing (Lancaster, 2011).

Therefore, based on previous studies, the present study aimed to discover the probable positive impact of "Graphic Organizer with Instructional Scaffolding" (GOIS) as a delivery mode on argumentative writing performance among TESL undergraduates. This study contributes to the Sociocultural theory (SCT) which focuses on the importance of social interaction and mediation in knowledge construction. Thus, in this study, the researchers have analysed the use of instructional scaffolding through social interaction and mediation. It includes an analysis of the role of the facilitator, peers and graphic organizers in the learning zone on the knowledge construction of argumentative writing of different groups using different delivery modes. This will enable educators to employ the SCT in the teaching and learning of argumentative academic writing to alleviate the problems experienced and encountered by TESL undergraduates which have been highlighted by past literature.

The outcomes of the present study provide more understanding of the use of graphic organizers and instructional scaffolding and will greatly contribute to the educators of TESL undergraduates to apply them in their teaching practices. Thus, the significance of this study can be ascertained from its contribution to research, practice and theory in the teaching of argumentative essay writing.

\section{MATERIALS AND METHODS}

Two types of instruments were employed in this study. They were the argumentative essay graphic organizer and pre-test and post-test argumentative essays. The graphic organizer was inclusive of three main sections, that is, the 'Introduction' with a 'Body Paragraph' and a 'Conclusion.' The 'Body Paragraph' section inclusive of three reasons, each with supporting details and shreds of evidence followed by the counterargument and rebuttal claim sections. The pre-test and post-test argumentative essay writing booklets consisted of an argumentative essay topic and clear instruction about the tests. 
An experimental research using a pre-test and post-test design was adopted to investigate the effect of graphic organizers on the overall argumentative essay writing performance. This design is suitable and appropriate for investigating the comparative effects of the GOIS and NGNI on the argumentative writing performance of the TESL undergraduates. This design includes a pre-test measure followed by intervention and a post-test. The TESL undergraduates identified for the study were two intact classes originally with 30 students $(n=30)$, one as the experimental group and another as the control group. The pre-test was implemented at the beginning of the research to evaluate prior knowledge of students' in argumentative essay writing. During the intervention period of four weeks, the experimental group went through four stages of learning using the graphic organizer as instructional scaffolding, Stage 1: The Introduction; Stage 2: Assisted Group Discussion; Stage 3: Writing an Individual Essay, and Stage 4: Peer Review. However, the control group went through lessons based on the lecture mode without the use of graphic organizers and instructional scaffolding. At the end of the intervention, a post-test was carried out to measure the argumentative essay writing performance. The main objective of the research is to identify the effect of graphic organizers and instructional scaffolding on the overall argumentative essay writing performance among TESL undergraduates. In line with this, the research question that guided the research is as follows:

Is there any significant difference in the overall argumentative essay writing performance between the GOIS and NGNI delivery modes?

A total of 60 students were identified and selected by the researchers, one as the experimental group $(n=30)$ and another as the control group $(n=30)$. Cohen, Manion and Morisson (2007) recommended 30 students as the sample size to reach a general conclusion about the population as a whole. Students' consent forms were distributed and collected with the help of the TESL coordinator in the university college to show evidence of the student's voluntary participation in the study. The equivalence of the experimental (GOIS) and control (NGNI) groups was determined based on their semester writing test score results and they were found to be homogeneous.

A conceptual framework (Figure 1) was designed by the researchers and used to guide and keep the present research on track.

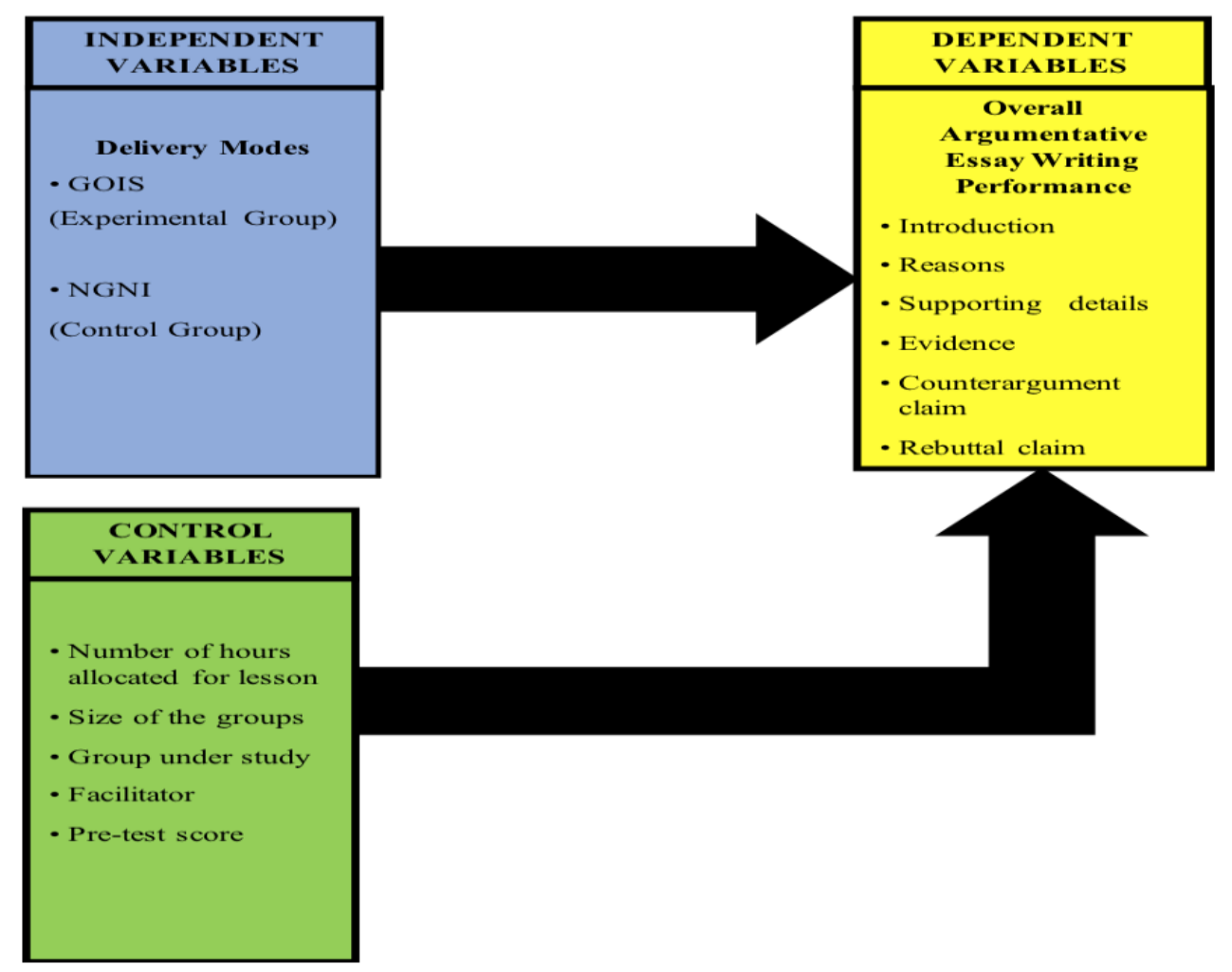

Figure 1. Conceptual Framework of the Study

The independent variables of this study are the delivery modes, which were operationalised in two conditions, that is, the GOIS and NGNI. The GOIS delivery mode function as the study intervention. The lecture method is included as a control condition, which is referred to as 'No Graphic Organizer No Instructional Scaffolding' (NGNI). The rationale for including the lecture 
method (NGNI delivery mode) as the control group is to enhance our understanding of the effectiveness of the present study intervention.

The dependent variable of this study is the overall argumentative essay writing performance and the constant or controlled variables of the study are the number of hours allocated for a lesson, the size and type of students involved in the study, the facilitator and lastly the pre-test score which acts as the covariate. The overall argumentative essay writing performance was measured as an overall construct and inclusive of seven categories, that is, the introduction, reason, supporting detail, evidence, counterargument claim, rebuttal claim, and conclusion. The introduction includes the first impression for the readers that describes the writer's point of view or claim and acts as a roadmap for the entire essay. The introduction is important as it grabs the readers' attention (Muniandy \& Ram, 2011). Next, the body paragraph which includes the reason that states the support for the claim and normally answers the question 'why'. Normally an argumentative essay requires three reasons and they justify why the writer's position is better. The supporting details include additional information to make each of the presented reason stronger. Supporting details are crucial as they support the writer's point of view and make the argument convincing. The evidence also comes in a paragraph and provides facts, examples, statistics or data connected to the writer's reasons and claim to convince the readers. The counter-argument claim, on the other hand, presents possible arguments against the writer's claim while the rebuttal claim presents the writer's response to the counter-argument claim. Finally, the conclusion includes the last section of the essay that summarizes the arguments and supporting points which are important to update the readers on its purpose, importance and features (Muniandy \& Ram, 2011).

The purpose of the pre-test and post-test in this study was to investigate the argumentative writing ability in terms of the overall argumentative essay writing performance of the two delivery modes, namely GOIS and NGNI. The pre-test was administered before the treatments but the post-test was administered after the treatments. The pre-test and post-test argumentative essay writing booklets consisted of an argumentative essay topic and clear instruction about the tests. In line with this, students were also required to fill in the following information; students' intake year, semester, course and date of the tests. The duration of time suggested for the pre-test and post-test was an hour. The number of words required for the test was 350 words as that was the word limit required in the TESL Diploma course. Besides, it is also suggested that for writing good essays, students need to practise the basic elements and it is best to practice in short and focused assignments (Yale University, 2016). The argumentative essay topics for the pre-test and post-test were varied and selected based on topics applicable to students' life. This is consistent with the "National Evaluation and Technical Assistance Center for the Education of Children and Youth Who Are Neglected, Delinquent or At-Risk" (NDTAC, 2006) which stated that administrators should not give the same questions to their students for the pre-test and post-test. The reason for this is to avoid students from producing invalid data as their improvement cannot be accredited to the skills they have developed if they are already familiar with the test questions. Thus, the improved performance cannot be attributed to improvement in skills but rather to their familiarity with the test.

The analytical scoring rubric used for scoring the argumentative essay writing performance was the 'Analytic Scoring Rubric for Argumentative Writing' (ASRAW) adapted from Stapleton and Wu (2015) which is based on Toulmin-like elements. This was further modified by the researchers to score the pre-test and post-test argumentative writing performance of the TESL undergraduates. Toulmin's model (1958) had been used by many scholars (Zainuddin, 2006; Qin \& Karabacak, 2010). The validity of the 'Scoring Guide for Toulmin's Criteria for Argumentation' lies as a basis for argumentative writing assessment where evaluators make assessments “... based on the clarity of the writer's problem statement and claim, the quality and quantity of data or reasons to support the claim, and the quality and quantity of warrants connecting data to the claim" (Saito, 2010, p.31).

The ASRAW rubric (Stapleton \& Wu, 2015) was constructed with the following scales; 0 and 5 for the 'claim' category, 0 to 10 for the 'counterargument claim/alternative points of view' and 'rebuttal claim', and 0, 10, 15, 20 and 25 for the 'data', 'counterargument data/supporting reasons for alternative point(s) of view' and 'rebuttal data' categories. In the present study, the ASRAW rubric was modified by the researchers with the following scales; 0 to 2 for 'introduction', 'counterargument claim', 'rebuttal claim' and 'conclusion' categories while 0 to 4 for the 'reason', 'supporting detail' and 'evidence' categories. The 'claim' category from the ASRAW rubric was changed to 'introduction' and the content was modified. Further, the 'reason', 'supporting detail' and 'evident' categories were added as a new category by the researchers by modifying the content from the category of 'counterargument data/supporting reasons for alternative point(s) of view'. The ASRAW rubric was modified by the researchers so that it can act as a clear structure for scoring the argumentative essay writing performance for the present study. The analytical scoring rubric that the researchers adapted is inclusive of seven divisions; introduction, reason, supporting detail, evidence, counterargument claim, rebuttal claim, and conclusion. The scores for the introduction (ranges from 0 to 2 ), reason, supporting detail and evidence (ranges from 0 to 4) and the counterargument claim, rebuttal claim and rebuttal claim (ranges from 0 to 2). The "analytical scoring is useful in the classroom since the results can help teachers and students identify students' strengths and learning need" (Jonsson \& Svingby, 2007, p.132)

To ensure the reliability of the scoring criteria for the overall pre-test and post-test argumentative essay writing performance, a total of 8 argumentative essays from the two delivery modes were rated by the researcher with another inter-rater and an interrater correlation was done between the two. Holsti's coefficient of reliability (1990 as cited in Qian, 2010) was used to check the

This publication is licensed under Creative Commons Attribution CC BY. 
inter-rater reliability for the overall argumentative essay writing performance. The result of the C.R. was above 0.75 which indicated excellent agreement from both raters and this is clearly illustrated in Table 1.

Table 1. Inter-rater Reliability for the Overall Argumentative Essay Writing Performance (Pre-test/Post-test)

\begin{tabular}{|c|c|c|c|c|c|c|c|}
\hline \multicolumn{4}{|c|}{ Pre-test } & \multicolumn{4}{|c|}{ Post-test } \\
\hline $\begin{array}{c}\text { Rater } \\
1 \\
(\mathrm{n} 1) \\
\end{array}$ & $\begin{array}{c}\text { Rater } \\
2 \\
(\mathrm{n} 2) \\
\end{array}$ & $\begin{array}{l}\text { Agree } \\
(\mathrm{m})\end{array}$ & $\begin{array}{c}\text { C.R. } \\
(2 \mathrm{~m} / \mathrm{n} 1+\mathrm{n} 2)\end{array}$ & $\begin{array}{c}\text { Rater } \\
1 \\
(\mathrm{n} 1) \\
\end{array}$ & $\begin{array}{c}\text { Rater } \\
2 \\
(\mathrm{n} 2)\end{array}$ & $\begin{array}{l}\text { Agree } \\
(\mathrm{m})\end{array}$ & $\begin{array}{c}\text { C.R. } \\
(2 \mathrm{~m} / \mathrm{n} 1+\mathrm{n} 2)\end{array}$ \\
\hline 8 & 8 & 6 & 0.75 & 8 & 8 & 7 & 0.88 \\
\hline
\end{tabular}

Keys: $\mathrm{m}=$ number of coding decisions agree by two judges

$\mathrm{n} 1=$ number of coding decisions made by judge 1

$\mathrm{n} 2=$ number of coding decisions made by judge 2

To ease the analysis, the 60 argumentative essays were grouped according to the two delivery modes. The experimental group with GOIS was tagged from GOIS01 to GOIS30 and the control group from NGNI01 to NGNI30.

\section{RESULTS}

It was hypothesized that there will not be any significant difference in the overall students' argumentative essay writing performance among the two groups. As indicated in the method section, to test this hypothesis, a pre-test and post-test argumentative essay was employed and measured for seven divisions: 'introduction,' 'reason,' 'supporting detail,' 'evidence,' 'counter-argument claim,' 'rebuttal claim,' and 'conclusion.' The scores for the 'introduction' (ranging from 0 to 2 ), 'reason,' 'supporting detail,' and 'evidence' (ranging from 0 to 4) and the 'counter-argument claim,' 'rebuttal claim,' and 'conclusion (ranging from 0 to 2 ) were used as the scale for measurement. The pre-test and post-test argumentative essays were marked to determine if the two delivery methods used for the TESL undergraduates had made any difference to their overall argumentative essay writing performance.

Analysis of the covariate (ANCOVA) was conducted to assess the effect of GOIS and NGNI delivery modes on the overall argumentative essay writing performance among TESL undergraduates after controlling the effect of pre-test of argumentative essay writing performance. The two assumptions of ANCOVA which are homogeneity of regression slopes $\mathrm{F}(1,58)=0.306$, $\mathrm{p}=0.582, \eta 2=0.005$ (Table 2 ) as well as the homogeneity of variance $\mathrm{F}_{(1,58)}=1.292,0.260$ were assumed (Table 3).

Table 2. Homogeneity Test of Regression Slopes for Overall Argumentative Essay Writing Performance

\begin{tabular}{lrrrrrr}
\hline \multicolumn{7}{c}{ Tests of Between-Subjects Effects } \\
\hline Source & $\begin{array}{c}\text { Type III Sum } \\
\text { of Squares }\end{array}$ & df & $\begin{array}{c}\text { Mean } \\
\text { Square }\end{array}$ & F & Sig. & $\begin{array}{c}\text { Partial Eta } \\
\text { Squared }\end{array}$ \\
\hline Corrected & $3685.404^{\mathrm{a}}$ & 3 & 1228.468 & 11.748 & .000 & .386 \\
Model & 3530.198 & 1 & 3530.198 & 33.760 & .000 & .376 \\
Intercept & 267.054 & 1 & 267.054 & 2.554 & .116 & .044 \\
Group & 336.918 & 1 & 336.918 & 3.222 & .078 & .054 \\
Pre-test & 32.046 & 1 & 32.046 & .306 & .582 & .005 \\
Group * Pre- & 5855.846 & 56 & 104.569 & & & \\
test & 186125.000 & 60 & & & & \\
Error & 9541.250 & 59 & & & & \\
Total & \multicolumn{7}{c}{ Corrected Total } & & & & & \\
\hline
\end{tabular}

Note: Dependent Variable: Overall Argumentative Essay Writing Performance (Post-test) a. $\mathrm{R}$ Squared $=.386($ Adjusted R Squared $=.353$ ) 
Table 3. Homogeneity Test of Variances for the Overall Argumentative Essay Writing Performance

\begin{tabular}{lccc}
\hline F & df1 & df2 & Sig. \\
\hline 1.292 & 1 & 58 & 0.260 \\
\hline Note: & *Dependent Variable: Argumentative Essay Writing Performance (Post-test) & \\
*Tests the null hypothesis that the error variance of the dependent variable is equal & across \\
groups & & \\
a. Design: Intercept + Pre-test + Group &
\end{tabular}

The result in Table 4 indicates that there is a significant difference in the overall argumentative essay writing performance between GOIS group (Mean=61.75, $\mathrm{SD}=1.870)$ and the NGNI group (Mean = 46.867, $\mathrm{SD}=1.869)$ at $\mathrm{p}<0.05$.

Table 4. Effect of Graphic Organizers and Instructional Scaffolding on the Overall Argumentative Essay Writing Performance among TESL Undergraduates

\begin{tabular}{|c|c|c|c|c|c|}
\hline \multicolumn{2}{|c|}{ Delivery Modes } & \multirow{2}{*}{$\begin{array}{c}\text { Mean } \pm \text { SD } \\
61.67 \pm 8.938\end{array}$} & \multirow{2}{*}{$\begin{array}{l}\text { Adjusted Mean } \\
61.75^{\mathrm{a}} \pm 1.870\end{array}$} & \multirow{2}{*}{$\begin{array}{c}\begin{array}{c}\text { Mean difference } \\
(95 \% \mathrm{CI})\end{array} \\
\mathrm{Re}\end{array}$} & \multirow{2}{*}{$\frac{\text { P-value }}{}$} \\
\hline GOIS & & & & & \\
\hline \multirow[t]{2}{*}{ NGNI } & & $46.83 \pm 11.633$ & $46.67^{\mathrm{a}} \pm 1.869$ & $15.009(8.577-21.442)$ & $<0.001^{\mathrm{b} *}$ \\
\hline & $\mathrm{F}$ & 32.96 & & & \\
\hline \multirow[t]{2}{*}{ ANCOVA } & $\mathrm{df}$ & 1,57 & & & \\
\hline & $\mathrm{p}$ & $<0.001 *$ & & & \\
\hline
\end{tabular}

Note: $* \operatorname{Re}=($ Reference group for comparison $)$

$\mathrm{SEM}=$ Standard error of the mean

a. Adjusted Mean

*b. Adjusted $\mathrm{P}$ value for multiple comparisons, Bonferroni $\mathrm{p}<0.05$

As noted in Table 3, the GOIS delivery mode was effective compared to the NGNI delivery mode in improving the overall argumentative essay writing performance among TESL undergraduates. As a result, this study rejects the null hypothesis and accepts the alternative hypothesis and concludes that there is a significant difference in the overall argumentative essay writing performance between the groups. Therefore, through systematic instructional scaffolding based on Ellis and Lantolf (2000) and learning environment involving interaction between facilitator and students was effective in improving the overall argumentative essay writing performance. Additionally, with facilitative tools such as the graphic organizers and strong mediation skills and guidance provided by the facilitator, a higher level of success in the argumentative essay writing performance had been achieved especially in the GOIS condition.

In this study, performance in the overall argumentative essay writing performance among the delivery modes, namely, GOIS and NGNI were analysed using the one-way ANCOVA followed by the Bonferroni's post hoc test. The results conclude that the overall argumentative essay writing performance was better when the GOIS delivery mode was adopted (61.75 \pm 1.870$)$ compared to the NGNI delivery mode $(46.67 \pm 1.869)(\mathrm{p}<0.001)$. As a whole, the GOIS delivery mode was better compared to the NGNI delivery mode in the overall argumentative essay writing performance of the groups.

The results of the present study implicate that there is a significant difference observed in the overall argumentative essay writing performance between the two groups. The GOIS group has outperformed the NGNI group. The positive effect of graphic organizers and instructional scaffolding on argumentative essay writing performance as evidenced in this study is in line with findings of previous studies (Sharrock, 2008; Lee \& Tan, 2010; Delrose, 2011; Hawkins, 2011; Huggins \& Edwards, 2011; Qin, 2013; Bishop et al., 2015; Meera \& Aiswarya, 2014; Obeiah \& Bataineh, 2015; Tayib, 2015; Mahmudah, 2016). 


\section{DISCUSSION AND CONCLUSION}

In review, the researchers believe the GOIS delivery mode had enabled the students in the experimental group to perform exceptionally well in the overall argumentative essay writing performance compared to their counterparts in the NGNI group. The GOIS delivery mode had enabled students to experience learning through the following mediation; facilitator and peers as human mediators and graphic organizers and language as symbolic tools. As proven in previous research, the findings of the present study showed that the facilitator in the GOIS group played an important role as a mediator in giving appropriate support so that the students could move towards independent learning (Obeiah \& Bataineh, 2015) and this could have helped the students to increase their skill and development (Ahmed, 2017) in their argumentative writing performance. This is also consistent with Vygotsky (1978) who asserted that a more experienced person can provide the students with scaffolding to support their evolving understanding of knowledge domains or development of complex skills. This was evident from students learning experiences which revealed that the GOIS group had experienced a supportive learning environment with the presence of the facilitator.

In the GOIS group, the facilitator's role was to offer students with explicit instruction and guidance using the graphic organizer that is tailored to their needs and as a result, enabled them to construct quality essays. This was consistent with the assertion made by a few scholars such as Lantolf and Thorne (2006) as well as Yang and Wilson (2006) that in a social environment, the help of peers and skilled educators are vital in learning. Additionally, a previous study had also revealed that ESL students who received scaffolded instruction from their facilitators were found to have outperformed in their academic writing performance compared to those without scaffolded instruction (Baradaran \& Sarfarazi, 2011).

The GOIS group was also found to interact actively by exchanging and sharing their ideas using the graphic organizers with their peers during group work activities and as a result, they were able to exchange and share their ideas. This is consistent with the sociocultural theory which is closely interlaced with collaboration in a real setting that allows students to view and come out with a conclusion through sharing ideas with their peers in the group (Majid \& Stapa, 2017). According to Shabani (2016), framing social interaction activities clearly and purposefully can lead to students' development. Therefore, the interaction process experienced by the GOIS group could have been the reason why the GOIS group has outperformed their counterparts in the overall argumentative essay writing performance.

Additionally, other possible reasons for students in the GOIS group to outperformed students in NGNI group can be interconnected to the teaching approach employed by the facilitator. The GOIS group has adapted a simple step-by-step instructional scaffolding approach from Ellis and Larkin (2000) which is inclusive of four learning stages using various approaches. This is in line with the view of Obeiah and Bataineh (2015) who stressed that a step-by-step approach and the amount of help provided by the facilitator in various stages can help students to become independent learners. In the GOIS condition, the facilitator employed the modelling and questioning approach at the beginning stage of the lesson to guide the students using the argumentative graphic organizer to write the argumentative essay. Therefore, the modelling and questioning approach could have helped students to stay active, focused and concentrate on their learning throughout the lesson and thus, aided the students to accomplish their argumentative tasks from the actual to potential level through interaction (Shi, 2017). The findings of this study are also congruent with the findings of López et al. (2017) that modelling significantly improves writing skill although employed for a short duration. According to Spectrum Newsletter (2008), if appropriate modelling according to students' needs, interest and abilities fail to meet the expectations, scaffolds will not help. However, this did not happen to the GOIS group. In line with this, students in the GOIS delivery mode were also instructed to work in small groups with the presence of a facilitator as evident in this study who provided guidance and help for students to work collaboratively in accomplishing the learning task. At the same time, during these collaborations, students could have shared their ideas, renegotiated their opinions and concluded as evident in this study from students' dialogue.

Furthermore, students went through various activities throughout their learning sessions, for instance, reading articles related to argumentative topics and completing the graphic organizers, drawing an argumentative essay graphic organizer and finally writing an individual essay. Thus, the facilitator could have applied his expertise in leading the learning process while students went through various activities and these could have transformed their interpersonal activities into inter-psychological activities gradually (Shi, 2017). Moreover, the role of students who are committed to contributing ideas to learn and the facilitator who provides encouragement and support to engage interaction between peers during group work (Webb et al., 2014) were evident in this study. Therefore, these may be the reason for the GOIS group to outperform students in the NGNI group in the overall argumentative essay writing performance. Additionally, the peer-review sessions where students had to exchange their essays with their peers, read and review them could have given the students opportunities to learn from each other and helped them to understand the mistakes that they may have overlooked. As a result, this would have provided opportunities for students to accommodate with different level of knowledge in order to progress in their learning to write the argumentative essay (Alibali, 2006). Therefore, the researchers believe these activities might have benefitted students in the GOIS group to outperform students in the NGNI group in the overall argumentative essay writing performance.

This publication is licensed under Creative Commons Attribution CC BY. 
ISSN 2250-3153

In line with these reasons, the group work activity using the graphic organizers to accomplish the argumentative tasks might have guided the students to interact and develop their argumentative writing skills. The findings are constant with Gagne and Parks (2013) who claimed that interaction during group work is capable of fostering learning through shared scaffolding which enables students to accomplish a given task successfully. Finally, the researchers believe the GOIS group which is supported by the sociocultural theory had outperformed the NGNI group as it is strongly inspired by the sociocultural theory which emphasized on social interactions that take place in meaningful contexts (Vygotsky, 1978).

Though research on the effect of graphic organizers and instructional scaffolding on argumentative writing in the educational field has been extensive, it is still relatively unexplored among TESL undergraduates, especially in the local context. This is expected as the use of graphic organizers and instructional scaffolding has not been widely adopted in higher education institutions despite having strong theoretical support in the sociocultural learning theory. As such, this research can contribute significantly to a better understanding of the instructional strategy. As mentioned earlier, this study had adopted experimental research using a pre-test and post-test research design. However, it must be conceded that there are some limitations to the study. The treatment sessions were limited and future research increases the sessions to ensure that the effectiveness of the instructional scaffolding process is determined more accurately. In terms of quantitative data analysis, this study had used the 'Analysis of Covariance' (ANCOVA) to analyse the effect of graphic organizers and instructional scaffolding on the overall argumentative writing performance among TESL undergraduates. Future studies might want to use the ANCOVA to analyse the effect of graphic organizers and instructional scaffolding in different contexts. However, to yield rich and solid data that would be useful in revealing uniqueness among the two groups; GOIS and NGNI, a qualitative analysis should also be conducted to obtain an in-depth understanding of the nature of the interaction processes in the argumentative writing among the groups with the different conditions.

In sum, the present study had revealed that the GOIS delivery mode has effectively transformed students' learning to be better than the NGNI delivery mode, which is conventional and still dominates over other methods in disseminating knowledge among TESL undergraduates in the local context. The GOIS delivery mode has been proven to be able to engage students in their learning and also promote students' argumentative writing performance better than the lecture mode (NGNI). The GOIS delivery mode which comprised group work activities had also enabled students to develop competencies such as cooperative learning, cognitive strength and personal skills that are vital for undergraduates. These were possible with the presence of interaction and graphic organizers as facilitative tools as well as strong mediation skills on the part of the facilitator who was able to provide systematic instructional scaffolding during the learning process. The result contradicts the claim made earlier by Verenikina (2008) who was doubtful about the benefits of instructional scaffolding. In fact, the use of graphic organizers and instruction scaffolding had also proven to be a better approach compared to the presently used lecture method in this institution where the study was conducted.

However, the potentials of graphic organizers and instructional scaffolding to promote higher tertiary level students' argumentative writing performance compared to the lecture method have yet to be adequately proved. Thus, the evidence on which delivery mode is more superior in enhancing argumentative writing performance is still inconclusive and needs to be explored further. As far as this study is concerned, the GOIS group had outperformed the NGNI group in the overall argumentative essay writing performance. Further, this study has indicated that GOIS delivery method has stimulated and harnessed students' interactions and should be given consideration in the teaching and learning of argumentative writing tasks among TESL undergraduates. The research ends with a strong recommendation that the use of graphic organizers and instructional scaffolding in groups to cater to students' interaction process can become an ideal strategy to be adopted by academicians in the process of teaching argumentative writing among not only for TESL undergraduates but also for all other graduates in higher academic institutions as the benefits would definitely enhance students' writing skills which are crucial for future employment.

\section{ACKNOWLEDGEMENTS}

The authors' deepest appreciation and credit go to all the TESL undergraduates who took part in the study. The authors truly appreciate their support and without their passionate participation and effort, this work could not have been possible. 


\section{REFERENCES}

[1] Abdul-Hafid Kamil, I. (2011). Perceptions of Kuwaiti EFL student-teachers towards EFL writing, and methods of teaching and learning EFL writing. (Unpublished doctoral dissertation). University of Exeter, UK. Retrieved from https://core.ac.uk/download/pdf/12826627.pdf

[2] Ahmed, S. (2017). Impact and implementation of sociocultural theory in ESL classroom (Doctoral dissertation, BARC University). Retrieved from http://dspace.bracu.ac.bd/xmlui/bitstream/handle/10361/9048/13303025_ENH.pdf?sequence=1\&isAllowed=y

[3] Alibali, M. (2006). Does visual scaffolding facilitate students' mathematics learning? Evidence from early algebra. Retrieved from http://ies.ed.gov/funding/grantsearch/details.asp?ID=54

[4] Allenger, M. S. (2015). Effects of teacher prompting techniques on the writing performance of Fourth and fifth graders. Retrieved fromhttp://mds.marshall.edu/cgi/viewcontent.cgi?article=1947\&context=etd

[5] Baradaran, A., \& Sarfarazi, B. (2011). The impact of scaffolding on the Iranian EFL learners' English academic writing. Australian Journal of Basic and Applied Sciences, 5(12), 2265-2273. Retrieved from http://ajbasweb.com/old/ajbas/2011/December-2011/2265-2273.pdf

[6] Berk, R. (2009). Teaching strategies for the next generation. Transformative Dialogues: Teaching \& Learning Journal, 3(2), 1-24. Retrieved from https://www.researchgate.net/publication/228346567_Teaching_strategies_for_the_net_generation

[7] Bipinchandra, J.S., Shah, P. M., Puteh, S. N., Din, R., Rahamat, R., \& Aziz, J. A. (2014). User needs analysis in learning argumentative writing via mobile platform. Procedia-Social and Behavioral Sciences, 118, 198-205. https://doi.org/10.1016/j.sbspro.2014.02.027

[8] Bishop, A. E., Sawyer, M., Alber-Morgan, S.R., \& Boggs, M. (2015). The Effects of a graphic organizer training package on the persuasive writing of middle school students with autism. Education and Training in Autism and Developmental Disabilities, 50(3), 290-302. Retrieved from https://www.researchgate.net/publication/286880871_Effects_of_a_Graphic_Organizer_Training_Package_on_the_Persuasive_Writing_of_Middle_School_ Students_with_Autismmiller

[9] Botley, S. P., \& Hakim, F. (2014). Argument structure in learner writing: a corpus-based analysis using argument mapping. Kajian Malaysia, 32(1), 45-77. https://brage.bibsys.no/xmlui/bitstream/handle/11250/2460792/ENGFREM_Damir\%20Budimlic.pdf? sequence=1\&isAllowed=ybacca

[11] Cho, K.L., \& Jonassen, D.H. (2002). The effects of argumentation scaffolds on argumentation and problem solving. Educational Technology: Research \& Development, 50(3), 5-22. Retrieved from https://pdfs.semanticscholar.org/e8d1/d969421ed0cf8c7461b0c6275e32171bf63a.pdf

[12] Chong, T.H., \& Teng, Y.T. (2018). The Effects of Experiential Learning on Teaching Perception and Learning Approachesamong Public Relations Students. SEARCH Journal of the South East Asia Research Centre for Communication and Humanities. 10(1), 79-108. Retrieved from http://search.taylors.edu.my/documents/journals/2018-10-1/SEARCH-2018-10-1-J4.pdf

[13] Chukwuagu, K. (2016). Effect of instructional scaffolding on academic achievement and interest of students' in chemistry in senior secondary schools in Mabitoli L.G.A. Retrieved from https://www.academia.edu/32200026/Effect_of_Instructional_Scaffolding_on_Academic_Achievement_and_Interest_of_Students_in_Chemistry_in_Senior_Secondary_Schools_in_Mabitoli_LG.A

[14] Cohen, L., Manion, L., \& Morisson, K. (2007). Research methods in education. (6th ed.). New York, USA: Routledge. Retrieved from https://islmblogblog.files.wordpress.com/2016/05/rme-edu-helpline-blogspot-com.pdf

[15] Dastjerdi, H. V., \& Samian, S. H. (2011). Quality of Iranian EFL learners' argumentative essays: Cohesive devices in focus. Mediterranean Journal of Social $\begin{array}{ll}\text { Sciences, 2(2), } & 65-76 . \\ \text { Retrieved }\end{array}$ https://www.researchgate.net/publication/285001233_Quality_of_Iranian_EFL_Learners'_Argumentative_Essays_Cohesive_Devices_in_Focus

[16] De Rycker, A., \& Ponnudurai, P. (2011). The effect of online reading on argumentative essay writing quality. GEMA Online® Journal of Language Studies, 11(3).
Retrieved https://www.researchgate.net/publication/267832826_The_Effect_Of_Online_Reading_On_Argumentative_Essay_Writing_Quality

[17] Delrose, L.N. (2011). Investigating the use of graphic organizers for writing. (Master's thesis). Retrieved from http://etd.lsu.edu/docs/available/etd-04122011 182849/unrestricted/THESIS.pdf

[18] Dexter, D.D., \& Hughes, C. A. (2011). Graphic organizers and students with learning disabilities: a meta-analysis. Learning Disability Quarterly, 34(1), 5172. https://doi.org/10.1177/073194871103400104vishop

[19] Ellis, E. S., \& Larkin, M. J. (1998). Strategic instruction for adolescents with learning disabilities. Learning about learning disabilities, $2,585-656$.

[20] Ellis, R. (2000). Task-based research and language pedagogy. Language Teaching Research, 4(3), $193-220$.

[21] Fergus, D. (2009). Scaffolding instruction and using graphic organizers for writing effective in-class summaries. (Master's thesis). Retrieved from http://search.proquest.com/openview/bd71d2c87c1a32911ba580799d4c9474/1?pq-origsite=gscholar\&cbl=18750\&diss=y

[22] French, S., \& Kennedy, G. (2016). Reassessing the value of university lectures. Retrieved from https://melbournecshe.unimelb.edu.au/_data/assets/pdf_file/0004/2774389/Reassessing-the-Value-of-University-Lectures.pdf

[23] Gagne, N., \& Parks, S. (2013). Cooperative learning tasks in a grade 6 intensive ESL class: Role of scaffolding. Language Teaching Research, 17(2), 188209. https://doi.org/10.1177/1362168812460818

This publication is licensed under Creative Commons Attribution CC BY. 
[24] Goh, P. S. C. (2008). Teaching practices that hinder the deep approaches to learning of twinning programme students in Malaysia: A qualitative perspective. $\begin{array}{llll}\text { The Asia-Pacific Education } & \text { Researcher, 17(1), } & \text { Retrieved }\end{array}$ https://pdfs.semanticscholar.org/072c/3b2d31314623012fa6bfbd2b074d085629fd.pdfjumaat

[25] Harvey, J. (2011). A sociocultural-theory-based study of the impact of mediation during post-observation conferences on language teacher learning. Retrieved from http://scholarcommons.usf.edu/etd/3727zulki

[26] Hawkins, L. (2011). The use of graphic organizers in supporting primary aged students in genre specific writing tasks. (Master's thesis). Retrieved from https://digitalcommons.brockport.edu/ehd_theses/17chuk

[27] Hillocks, G. (2011). Teaching argument writing, grades 6-12: Supporting claims with relevant evidence and clear reasoning. Portsmouth, NH: Heinemann.botley

[28] Huggins, E., \& Edwards, R. (2011). Scaffolding to improve reading comprehension and to write a scholarly research paper. International Journal of Humanities and Social Science. 1(16), 30-36. Retrieved from http://www.ijhssnet.com/journals/Vol_1_No_16_November_2011/4.pdf

[29] Hussin, S. (2008). Creating a bigger ZPD for ESL learners via online forum in Malaysia. College Teaching Methods \& Styles Journal, 4(11), 1-10. doi:10.19030/ctms.v4i11.5575

[30] Jonsson, A., \& Svingby, G. (2007). The use of scoring rubrics: Reliability, Validity and Educational consequences. Educational Research Review, 2, 130144. doi:10.1016/j.edurev.2007.05.002

[31] Jumaat, N. F., \& Tasir, Z. (2014, April). Instructional scaffolding in online learning environment: A meta-analysis. In 2014 International Conference on Teaching and Learning in Computing and Engineering (pp. 74-77). IEEE. https://doi.org/10.1109/LaTiCE.2014.22

[32] Ka-kan-Dee, M., \& Kaur, S. (2015). Teaching strategies used by Thai EFL lecturers to teach argumentative writing. Procedia- Social and Behavioral Sciences, 208, 143 -156. https://doi.org/10.1016/j.sbspro.2015.11.191

[33] Kanestion, A., Singh, M. K. S., Shamsudin, S., Isam, H., Kaur, N., \& Singh, G. P. (2016). Lexical verbs in Malaysian university English test argumentative essays: A corpus-based structural analysis. International Review of Management and Marketing, 6(8S), 13-17. https://doi.org/10.15405/epsbs.2016.08.56ni

[34] Kellogg, R. \& Whiteford, A. (2009). Training advanced writing skills: The case for deliberate practice. Educational Psychologist, 44(4), 250-260. https://doi.org/10.1080/00461520903213600

[35] Kelly, M. (2017). Lectures in schools. Pros and cons. Retrieved from https://www.thoughtco.com/lecture-pros-and-cons-8037

[36] Kepol, N. (2017). Quality Malaysian English language teachers: Examining a policy strategy. Malaysian Journal of Learning and Instruction, 14(1), 187209. Retrieved from https://files.eric.ed.gov/fulltext/EJ1150438.pdfgoh

[37] Kohler, P. (2009). Don't just tell me; Show me: Using graphic organizers effectively. The Teaching Professor. Magna Publication, 23(6), 1-8. Retrieved from http://augmenting.me/cte/resources/newsletters_archive/TP090607.pdf

[38] Lancaster, Z. (2011). Interpersonal stance in L1 and L2 students' argumentative writing in economics: Implications for faculty development in WAC/WID programs. Across the Disciplines, 8(4), 21. Retrieved from https://wac.colostate.edu/atd/ell/lancaster.cfm

[39] Lantolf, J. P., \& Thorne, S. L. (2006). Sociocultural theory and the genesis of second language development. Oxford, UK: Oxford University Press.

[40] Lap, T. Q., \& Truc, N. T. (2014). Enhancing Vietnamese learners' ability in writing argumentative essays. The Journal of Asia TEFL, 11(2), 63-91.

[41] Larkin, M. (2002). Using Scaffolded Instruction to Optimize Learning. Retrieved from https://files.eric.ed.gov/fulltext/ED474301.pdf

[42] Lee, C. C., \& Tan S. C. (2010). Scaffolding writing using feedback in students' graphic organizers - novice writers' relevance of ideas and cognitive loads. Educational Media International, 47(2), 135-152.

[43] Lee, C.C. (2007). Graphic organisers as scaffolding for students' revision in the pre-writing stage. In ICT: Providing choices for learners and learning. Proceedings ascilite Singapore 2007. Retrieved from http://www.ascilite.org.au/conferences/singapore07/procs/lee-cc.pdf

[44] López, P., Torrance, M., Rijlaarsdam, G., \& Fidalgo, R. (2017). Effects of direct instruction and strategy modeling on upper-primary students' writing development. Frontiers in psychology, 8, 1054. https://doi.org/10.3389/fpsyg.2017.01054

[45] Mahmudah, I. (2016). Using graphic organizers to improve the writing skill of IX grade students of SMPN 9 Yogyakarta in the academic year of 2014/2015. English Language Teaching Journal, 5(3). Retrieved from http://journal.student.uny.ac.id/ojs/index.php/elt/article/view/3021/2700

[46] Majid, A. H. A., \& Stapa, S. H. (2017). The use of scaffolding technique via facebook in improving descriptive writing among ESL learners. 3L: Language, Linguistics, Literature ®, 23(4), 77-88. https://doi.org/10.17576/3L-2017-2304-07

[47] Malaysia Today. (November, 2005). Malaysia has 60,000 graduates unemployed. Retrieved from http://www.malaysia-today.net/Blog-e/2005/11/malaysiahas-60000- undergraduates.htm

[48] Mann, S. (2009). Students. Why do 60\% of students find their lectures boring? Retrieved from https://www.theguardian.com/education/2009/may/12/university-teaching

[49] Meera, P., \& Aiswarya, K. (2014). A study on the effectiveness of graphic organizers in the writing skill of English among secondary school students. Scholars World, 2(4), 72-82.

This publication is licensed under Creative Commons Attribution CC BY. 
[50] Mercer, N. (2008). Talk and development of reasoning and understanding. Human Development, 51, 90-100. https://doi.org/10.1159/000113158

[51] Miller, S.A. (2011). Using graphic organizers to increase writing performance. (Master's thesis). Retrieved from http://dspace.sunyconnect.suny.edu/bitstream/handle/1951/57455/Stephanie_Miller_Maters_Project_December2011.pdf?sequence=1

[52] Mohamed, N. (2016). Use of conjunctions in argumentative essay by ESL undergraduates. e-Academia Journal UiTMT, 5(1), 1-13. Retrieved from https://journale-academiauitmt.uitm.edu.my/v2/images/vol5issue12016/PID13-TheUseofConjunctionsinArgumentativeEssaybyESLUndergraduates.pdf

[53] Muftah, H. (2014). Conjunctions in argumentative writing of Libyan tertiary students. English Language Teaching, 7(3), p.108. doi:10.5539/elt.v7n3p108

[54] Muniandy, J., \& Ram, R. (2011). A guide to easy essay writing. Subang Jaya, Kuala Lumpur: Pelanduk Publications (M) Sdn. Bhd.

[55] National Evaluation and Technical Assistance Center for the Education of Children and Youth Who Are Neglected, Delinquent, or At-Risk (NDTAC). (2006). A brief guide to selecting and using pre-post assessments. Retrieved from http://www.neglected-delinquent. org/nd/docs/guide_prepost.pdf.st

[56] Nippold, M. A., \& Ward-Lonergan, J. M. (2010). Argumentative writing in pre-adolescents: The role of verbal reasoning. Child Language Teaching and Therapy, 26(3), 238-248. https://doi.org/10.1177/0265659009349979

[57] Noor, M. (2014). Dialogue, new media and children's intellectual development: Re-thinking Malaysian teaching and learning approaches. (Doctoral dissertation). Retrieved from https://uhra.herts.ac.uk/handle/2299/14953

[58] Nussbaum. E.M. \& Schraw, G. (2007). Promoting argument-counterargument integration in students' writing. The Journal of Experimental Education, 76(1). https://doi.org/10.3200/JEXE.76.1.59-92

[59] Obeiah, S. F., \& Bataineh, R. F. (2015). Does scaffolding-based instruction improve writing performance? The case of Jordanian EFL learners. Lublin Studies in Modern Languages and Literature, 39(2), 106. https://doi.org/10.17951/1smll.2015.39.2.1061

[60] Ponnudurai, P. (2011). Impact of ICT on argumentative content and vocabulary usage. In International Conference "ICT for Language Learning." (4 ${ }^{\text {th }}$ ed.). Retrieved from http://citeseerx.ist.psu.edu/viewdoc/download?doi=10.1.1.468.9898\&rep=rep1\&type=pdf

[61] Qian, L. (2010). A comparative genre analysis of English argumentative essays written by English major and non-English major students in an EFL context. (Master's thesis). Retrieved from http://sutir.sut.ac.th:8080/sutir/bitstream/123456789/3730/2/Fulltext.pdf

[62] Qin, J. \& Karabacak, E. (2010). The analysis of Toulmin elements in Chinese EFL university argumentative writing. System, 38(3), 444-456. https://doi.org/10.1016/j.system.2010.06.012

[63] Rahimi, M., \& Noroozisiam, E. (2013). The effect of strategies-based instruction on the improvement of EFL learners' writing quality: A sociocultural approach. Sage Open, 3(2). https://doi.org/10.1177/2158244013494222

[64] Sahin, C., Bullock, K, \& Stables, A. (2002). Teachers' beliefs and practices in relation to their beliefs about questioning at key stage 2. Educational Studies, 28(4), 371-384. https://doi.org/10.1080/0305569022000042390a

[65] Saito, S. (2010). An analysis of argumentative essays of Thai third-year English major instructed by the integrated process-genre approach. (Unpublished thesis). Srinakharinwirot University, Bangkok. Retrieved from http://thesis.swu.ac.th/swuthesis/Eng(M.A.)/Siwaporn_S.pdf

[66] Shabani, K. (2016). Applications of Vygotsky's sociocultural approach for teachers' professional development. Cogent education, 3(1). http://dx.doi.org/10.1080/2331186X.2016.1252177

[67] Sharrock, T. (2008). Effect of graphic organizers on students' writing. Action research. Kennesaw State University. Retrieved from https://commons.kennesaw.edu/gpc/sites/commons.kennesaw.edu.gpc/files/Paper\%20Sharock_0.pdf

[68] Shi, H. (2017). The theoretical interpretation of EFL teacher's professional development from the perspective of sociocultural theory. Theory and Practice in Language Studies, 7(11), 1059-1064. http://dx.doi.org/10.17507/tpls.0711.14

[69] Spawa, C.M.C. \& Hassan, F. (2013). "I doesn't know English": Beliefs and practices in the teaching of speaking in ESL classroom. Pertanika J. Soc. Sci. \& Hum. 21(2), 449-460. Retrieved from http://pertanika.upm.edu.my/Pertanika\%20PAPERS/JSS...moha

[70] Spectrum Newsletter. (Fall 2008). Instructional scaffolding to improve learning. Retrieved from https://niu.edu/spectrum/archives/scaffolding.shtml

[71] Stapleton, P., \& Wu, Y. A. (2015). Assessing the quality of arguments in students' persuasive writing: A case study analysing the relationship between surface structure and substance. Journal of English for Academic Purposes, 17, 12-23. http://dx.doi.org/10.1016/j.jeap.2014.11.006

[72] Tayib, A.M. (2015). The effect of using graphic organizers on writing (A case study of preparatory college students at Umm-Al-Qura University). International Journal of English Language and Linguistics Research, 3(1), 15-36. Retrieved from http://www.eajournals.org/wp-content/uploads/The-Effectof-Using-Graphic-Organizers-on-Writing.pdf

[73] Thompson, V. (2017). What a student learns from writing an argumentative essay. Retrieved from http://penandthepad.com/student-learns-writingargumentative-essay-2088.html

[74] Tucker, P. D., \& Strorage, J. H. (2005). Linking teacher evaluation and student learning. Alexandria, Virginia: Association for Supervision and Curriculum Development.

[75] Uzun, K. (2017). The use of conjunctions and its relationship with argumentative writing performance in an EFL setting. The Joumal of Teaching English for Specific and Academic Purposes. Vol. 5(2), pp.307-315. DOI: 10.22190/JTESAP1702307Uhillocks

This publication is licensed under Creative Commons Attribution CC BY. 
ISSN 2250-3153

[76] Vacca, R.T., Vacca, J.L., \& Mraz, M. (2011). Content area reading: Literacy and learning across the curriculum (10th ed.). Boston, MA: Pearson.mae

[77] Verenikina, I. (2008). Scaffolding and learning: its role in nurturing new learners. Retrieved from http://ro.uow.edu.au/cgi/viewcontent.cgi?article=1043\&context=edupapers

[78] Webb, N. M., Franke, M. L., Ing, M., Wong, J., Fernandez, C. H., Shin, N., \& Turrou, A. C. (2014). Engaging with others' mathematical ideas: Interrelationships among student participation, teachers' instructional practices, and learning. International Journal of Educational Research, 63, 79-93. https://doi.org/10.1016/j.ijer.2013.02.001

[79] Wilson, A. H. (2014). The effects of scaffolded instruction in the Toulmin Model of argument on the problem-solving strategies of four sixth grade writers. (Doctoral dissertation) Retrieved from https://drum.lib.umd.edu/bitstream/handle/1903/16278/Wilson_umd_0117E_15792.pdf?sequence=1\&isAllowed=ycho

[80] Yale University. (2016). Teaching students to write good papers. Retrieved from http://ctl.yale.edu/teaching/ideas-teaching/teaching-students-write-goodpapers

[81] Yang, L., \& Wilson, K. (2006). Second language classroom reading: A social constructivist approach. The Reading Matrix, 6(3), 364-372. Retrieved from https://www.researchgate.net/publication/255587044_SECOND_LANGUAGE_CLASSROOM_READING_A_SOCIAL_CONSTRUCTIVIST_APPROAC $\mathrm{H}$

[82] Zainuddin, S. Z. (2006). Effects of training in the use of argumentative structures on ESL students' argumentative writing ability (Master's thesis, Universiti Putra Malaysia). Retrieved from http://psasir.upm.edu.my/id/eprint/510/1/600368_fbmk_2006_7_abstrak_je_(dh_pdf).pdf

[83] Zakrajsek, T. (2018). Reframing the lecture versus active learning debate: Suggestions for a new way forward. Education in the Health Professions, 1(1), 1-3. Retrieved from http://www.ehpjournal.com/text.asp?2018/1/1/1/242551ma

[84] Zulkurnain, N., \& Kaur, S. (2014). Oral English communication difficulties and coping strategies of Diploma of Hotel Management students at UiTM. 3L: Language, Linguistics, Literature ${ }^{\circ}, 20(3), 93-112$. Retrieved from http://journalarticle.ukm.my/7741/

\section{AUTHORS}

First Author- Jayasri Lingaiah, PhD, Faculty of Social Sciences \& Liberal Arts, UCSI University, Kuala Lumpur, Malaysia, jayasri66@ymail.com

Second Author- Saroja Dhanapal, PhD, Faculty of Law, University of Malaya, Kuala Lumpur, Malaysia, saroja.dhanapal@um.edu.my

Correspondence Author - Jayasri Lingaiah, jayasri66@ymail.com, 0122502853

This publication is licensed under Creative Commons Attribution CC BY. 